\title{
Proposal for archival reference collections of chromosomal DNA from uncultivated bacterial species
}

Uncultured micro-organisms are being identified with increasing frequency in animal and plant hosts as well as in diverse natural environments. For a number of uncultured organisms, it is possible to obtain genomic DNA in a quite pure state free from host DNA or the DNA of surrounding bacteria. For example, DNA can be isolated from uncultured mycoplasmas that have been separated from host tissues or blood by elution and differential (or gradient) centrifugation. If moderate amounts of material are available, full-length chromosomal DNA can be isolated by pulsed-field gel electrophoresis and the DNA cloned (Neimark \& Kirkpatrick, 1993; Neimark et al., 1998; Liefting \& Kirkpatrick, 2003). Similarly, uncultured 'extremophiles' that inhabit extreme environments are often highly enriched in their habitats and may be separated for DNA isolation.

I propose that DNA obtained from uncultured Candidatus species that have been published in a peer-reviewed journal be deposited in a bacterial reference collection. Deposits would be voluntary and would not be a requirement for publication. This DNA would serve as an archival reference and permit analysis and cloning of additional genes of interest from a commonly available repository.

The reference DNA can be provided conveniently by submitting DNA samples on FTA (Flinders Technology Associates) filter papers (Whatman; similar-purpose papers are made by Schleicher and Schuell but my experience with these is limited). DNA spotted on FTA filter paper can be stored at ambient temperature for at least 14 years without degradation and requires little storage space. Small disks (approx. $3 \mathrm{~mm}$ in diameter) or squares can be punched or cut from the filters to provide multiple DNA samples which are readily prepared for PCR analysis. Because micro-organisms applied to the FTA filters are inactivated by protein denaturation and cell lysis, DNA samples obtained from pathogens can be handled safely and can be distributed inexpensively by mail.

From the standpoint of a culture collection, the burden and expense of maintaining a collection of pre-cut filter segments would be small and contributors would provide a data page that could be reproduced and distributed with specimens. Where supply is limited, the culture collection could be relieved from deciding distribution priorities by referring investigators, possibly by a statement in the catalogue, to a standing committee of the appropriate society for that organism (the International Union of Microbiology Societies has organism committees and some specialist organism societies have standing committees and reagent repositories). A committee of the bacteriology curators at the American Type Culture Collection (ATCC) has already agreed in principle to accept mycoplasma DNA samples on FTA filters. Specialist societies such as, for example, a consortium of phytopathology or entomological societies might also maintain DNA repositories.

In discussing this notion with colleagues, I commented that someone must have thought about this before. Indeed, I thank one of the three referees who reviewed this letter for bringing to my attention the paper by Sneath (1995), in which he made a somewhat similar proposal. Sneath proposed, as an alternative to the expense of maintaining ever larger collections of live organisms, that non-living bacterial specimens be preserved as dried material from which DNA could be recovered for future study and that such material would also be useful for 'uncultivable' micro-organisms. He also pointed out that the International Code of Nomenclature of Bacteria (Lapage et al., 1992) made provision for preserved material to be the type of 'uncultivable' bacteria. (The term 'uncultivable' should be replaced with 'uncultivated' or 'uncultured', since cultivation in future cannot be ruled out and may be achieved in some cases by employing new knowledge and advancing methods, including genomic complementation.)

\section{Harold Neimark}

Department of Microbiology and Immunology, Box 44, Morse Institute for Molecular Genetics, College of Medicine, State University of New York, 450 Clarkson Avenue, Brooklyn, NY 11203, USA

\section{Correspondence: Harold Neimark} (neimah25@hscbklyn.edu)

Lapage, S. P., Sneath, P. H. A., Lessel, E. F., Skerman, V. B. D., Seeliger, H. P. R. \& Clark., W. A. (editors) (1992). International Code of Nomenclature of Bacteria (1990 Revision). Bacteriological Code. Washington, DC: American Society for Microbiology.

Liefting, L. W. \& Kirkpatrick, B. C. (2003). Cosmid cloning and sample sequencing of the genome of the uncultivable mollicute, Western $\mathrm{X}$-disease phytoplasma, using DNA purified by pulsed-field gel electrophoresis. FEMS Microbiol Lett 221, 203-211.

Neimark, H. \& Kirkpatrick, B. C. (1993). Isolation and characterization of full-length chromosomes from non-culturable plant-pathogenic Mycoplasma-like organisms. Mol Microbiol 7, 21-28.

Neimark, H., Mitchelmore, D. \& Leach, R. H. (1998). An approach to characterizing uncultivated prokaryotes: the Grey Lung agent and proposal of a Candidatus taxon for the organism, 'Candidatus Mycoplasma ravipulmonis'. Int J Syst Bacteriol 48, 389-394.

Sneath, P. H. A. (1995). Taxonomic note: the potential of dead bacterial specimens for systematic studies. Int J Syst Bacteriol 45, 188-189. 